\title{
Modification of alpha-Zirconium Phosphate Synthesis - Effects of Crystallinity and Acidity on Eu(III) and Am(III) lon Exchange
}

\section{Wiikinkoski, Elmo W.}

2018-09-07

Wiikinkoski , E W , Xu , J , Zhang , W , Hietala , S \& Koivula , R T 2018 , ' Modification of alpha-Zirconium Phosphate Synthesis - Effects of Crystallinity and Acidity on Eu(III) and Am(III) lon Exchange ' , ChemistrySelect, vol. 3 , no. 33 , pp. 9583-9588 . https://doi.org/10.1002/slct.201801601

http://hdl.handle.net/10138/322248

https://doi.org/10.1002/slct.201801601

acceptedVersion

Downloaded from Helda, University of Helsinki institutional repository.

This is an electronic reprint of the original article.

This reprint may differ from the original in pagination and typographic detail.

Please cite the original version. 


\title{
Modification of $\alpha$-Zirconium Phosphate Synthesis - Effects of Crystallinity and Acidity on $\mathrm{Eu}(\mathrm{III})$ and $\mathrm{Am}$ (III) lon Exchange
}

\author{
Elmo W. Wiikinkoski, ${ }^{* 1}$ Junhua $X u,{ }^{1}$ Wenzhong Zhang, ${ }^{1}$ Dr. Sami Hietala, ${ }^{2}$ Dr. Risto T. Koivula ${ }^{1}$
}

${ }^{1}$ Department of Chemistry - Radiochemistry, University of Helsinki. ${ }^{2}$ Department of Chemistry, University of Helsinki. Address: A.I. Virtasen aukio 1, P.O. Box 55, 00014 University of Helsinki, Finland

*Corresponding author: elmo.wiikinkoski@helsinki.fi

\section{Abstract}

The aim of an ongoing study is to develop ion exchange materials to be used in low pH in mineral acids for the uptake and separation of trivalent lanthanides and actinides. We present material development of $\alpha$-zirconium phosphate (ZrP), namely the effects of its crystallinity and acidity on other material properties and on Eu(III) and Am(III) trace ion exchange. One-pot synthesis for three ZrP products having a time for (re)crystallization of 1 hour, 5 hours and 25 hours, is reported. Characterization techniques include X-ray diffraction, solid-state nuclear magnetic resonance,

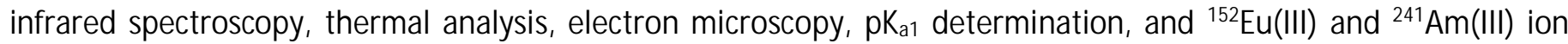
exchange studies, i.e. distribution-, selectivity- and metal binding coefficient determinations. As crystallinity and crystallite size increase, so do Eu(III) and Am(III) metal binding coefficients. The acidity and Eu(III) and Am(III) distribution- and selectivity coefficients increase in the reverse order. Findings are discussed with separation in mind. Promising separation factors (Eu:Am) of up to 90 were achieved in pH less than 1 in nitric acid.

\section{Introduction}

Partitioning and transmutation (P\&T) is a hot topic in the international spent nuclear fuel research. It is known that actinides plutonium, americium and curium, contribute to the majority of the radiotoxicity of spent nuclear fuel in long term. The approach of P\&T is to burn these elements in novel reactors. However, the presence of numerous fission products inhibit the burning of the actinides, hence the need for partitioning. Spent nuclear fuel is commonly first dissolved in strong acids after which different separation strategies are applied. Partitioning of uranium-plutonium is already widely proven, and processes such as PUREX are in use. The most difficult separation is then that of the actinides Am(III) and $\mathrm{Cm}$ (III), dominant in radiotoxicity after plutonium separation, from the chemically similar fission products, the trivalent lanthanides.

The majority of current actinide-lanthanide separation methods in use are based on solvent extraction. The drawbacks of these methods include generation of large volumes of secondary waste streams, and the limited radiolytic stability of the used organic extractants. Thus there is an interest of finding suitable separation method that utilizes mainly inorganic materials and aqueous streams. Ion exchange can offer such advantages.

In our study, we approach the partitioning problem by the means of inorganic ion exchange materials that can separate actinides from lanthanides, in simple mineral acids. From the exchanger, this requires great selectivity differences between elements. Such selectivity differences can stem from the slight differences in size, or charge density, of the analyte ions. The differences can be quantified by the use of parameters such as selectivity coefficient and metal binding coefficient. Inorganic ion exchange can offer great thermal, chemical and radiolytic stability, and low waste volumes. Highly selective material, however, easily accumulates a large amount of radioactivity in a small volume, resulting in a tough process design. It is not trivial to separate trivalent actinides from trivalent lanthanides with ion exchange because of their severe physicochemical similarities. High differences in the selectivities for these groups are needed from the exchange material. When such capable materials are found, it is important to closely study the reasons for 
the differences in the selectivities, to further develop even better exchangers for the separation.

Herein we focus on the inorganic ion exchanger $\alpha$ zirconium phosphate (abbreviated as $\alpha$-ZrP, or ZrP when talking about the whole family of zirconium phosphate materials), first reported by $A$. Clearfield and J. A. Stynes in 1964. ${ }^{[1]} \mathrm{M}$ etal(IV) phosphates that have layered structure, ${ }^{[2]}$ such as $\alpha-Z r P$, are multipurpose materials under study since mid-20 ${ }^{\text {th }}$ century, ${ }^{[1,3]}$ with major contributions throughout the years by $A$. Clearfield and G. Alberti. In later decades the research on ZrP has continually increased. Major research topics on $\alpha$-ZrP include cation exchange ${ }^{[1,4]}$ and catalysis. ${ }^{[5]}$ It was discovered that the interlayer of these layered materials is versatile and susceptible to modifications which lead to the ever-increasing interest also on their organic-hybrid compounds, such as the zirconium phosphonates. ${ }^{[6]}$ The first zirconium phosphonates retaining the layered structure of ZrP were synthesized by G. Alberti et al. in 1978. ${ }^{[6 a]}$ In recent years, ZrP research has taken additional novel directions, such as drug delivery systems ${ }^{[7]}$ and surface modified multifunctional materials. ${ }^{[8]}$ For majority of novel use cases for ZrPs, intercalation of organic compounds to widen the interlayer distance ( $7.6 \AA$ in $\alpha$-ZrP) is done to accommodate larger guest species or further modification of the product. We study the simple $\alpha$-ZrP on its ion exchange properties for it is suitable for small cationic species.

$\alpha-Z r P$ is a weakly acidic bifunctional compound and has the composition of zirconium bis(monohydrogen orthophosphate) monohydrate, $\mathrm{Zr}\left(\mathrm{HPO}_{4}\right)_{2} \cdot \mathrm{H}_{2} \mathrm{O}{ }^{[2 \mathrm{~b}]}$ It serves our purpose of radioactive waste separations because of its robustness: high radiolytic stability, ${ }^{[9]}$ high thermal stability and chemical stability in strong acids. ${ }^{[10]}$ Ion exchange related research on $\alpha$-ZrP has traditionally focused on mono- and divalent ions $s^{[4]}$. There are some studies, ${ }^{[10-11]}$ that we believe to be too few, on zirconium phosphates and phosphonates on the topic of trivalent actinide and lanthanide uptake or separation, for the promise it shows as a highly ion selective material for also trivalent ions.

Our preliminary results on three $\alpha$-ZrP products for $\mathrm{Am}(\mathrm{III})$ and $\mathrm{Eu}(\mathrm{III})$ selectivity investigation are reported elsewhere. ${ }^{[11 f]}$ It was shown that for these materials, there are selectivity differences for americium and europium in nitric acid. The $\mathrm{pH}$ range of 0 to 3 was studied and it was shown that in this range, separation factors up to 40 could be achieved for the pair $\mathrm{Eu}(\mathrm{III}) / \mathrm{Am}$ (III) indicating a clear preference for europium. However, the synthesis for three different products were largely different, as were the starting reagents, resulting in unclear reasons for difference in metal affinities between the materials. It was then the idea to select just one synthesis route and modify it, and analyse what changes in the material result in a greater separation factors. The approach here is a onepot synthesis with a slight differences in conditions for separate aliquots.

\section{Results and Discussion}

\section{Structure, composition and morphology}

The syntheses of ZrP1, ZrP5 and ZrP25 differed by reflux time. Thus there was expected to be differences in their crystallinity and because of this, further in their acidity and ion exchange properties, based on the findings we have reported earlier ${ }^{[11 f]} X$-ray diffraction patterns were measured to identify crystalline phases of the products (Fig. 1). All patterns correspond to the well-known $\alpha$-zirconium phosphate, and no other known phases such as $\gamma$-zirconium phosphate are found. It is noted that peaks get more defined as the reflux time increases, indicating a higher degree of crystallinity. Unit cell parameters (Table 1) for the monoclinic crystal structure of space group $\mathrm{P} 2_{1} / \mathrm{c}$ were calculated with UnitCell software ${ }^{[12]}$ from the measured XRD data. The crystallite sizes for each product were calculated from the full width at half maximum values using the Scherrer equation (Table 1). Several shape factors are included as the particle morphology is very different across the three products, but as these factors are arbitrary, only estimates on the crystallite size are possible. Crystallite size greatly increases as the time for recrystallization increases. Even though crystallite size increases, particle size decreases as less and less large aggregates are formed, see electron microscopy. It was determined that as the time for recrystallization increases, cell volume is slightly decreased (Table 1). The parameters are within just one or two percent in all cases, although the trends are consistent: for ZrP1 to ZrP5 to ZrP25, parameters a and $b$ increase while $c, \beta$ and volume decrease. FTIR measurements were done with attenuated total reflectance method, and it was found that the strong absorptions in the region $950 \mathrm{~cm}^{-1}$ to $1100 \mathrm{~cm}^{-1}$ attributed to orthophosphate group increased in the order ZrP1 <ZrP5 <ZrP25. see Supporting Information for FTIR procedure and spectra. 
Table 1. Unit cell parameters ( $a, b, c, \beta$ and cell volume) and their uncertainties. Scherrer crystallite sizes ( $\tau$ ) for ZrP1, ZrP5 and ZrP25 calculated from the major peak at the tabulated $2 \theta$ value for several shape factors $(\mathrm{K})$.

\begin{tabular}{|c|c|c|c|c|c|c|}
\hline & ZrP1 & Uncertainty $(1 \sigma)$ & ZrP5 & Uncertainty $(1 \sigma)$ & ZrP25 & Uncertainty $(1 \sigma)$ \\
\hline$a(\AA)$ & 9.0486 & 0.0011 & 9.0890 & 0.0009 & 9.0845 & 0.0009 \\
\hline$b(\AA)$ & 5.3072 & 0.0005 & 5.3132 & 0.0005 & 5.3140 & 0.0005 \\
\hline$c(\AA)$ & 16.614 & 0.006 & 16.347 & 0.003 & 16.303 & 0.003 \\
\hline$\beta\left(^{\circ}\right)$ & 111.98 & 0.013 & 111.528 & 0.009 & 111.511 & 0.009 \\
\hline $\begin{array}{ll}\text { Cell vol. } & \text { vol } \\
\left(\AA^{3}\right) & \end{array}$ & 739.84 & 0.15 & 734.35 & 0.10 & 732.22 & 0.10 \\
\hline & $2 \theta\left({ }^{\circ}\right)$ & FWHM $\left({ }^{\circ}\right)$ & $\begin{array}{l}\tau(\mathrm{nm}) \\
\mathrm{K}=0.95\end{array}$ & $\begin{array}{l}\tau(\mathrm{nm}) \\
\mathrm{K}=0.90\end{array}$ & $\begin{array}{l}\tau(\mathrm{nm}) \\
\mathrm{K}=0.8\end{array}$ & \\
\hline ZrP1 & 11.39 & 0.7586 & 13.30 & 12.60 & 11.20 & \\
\hline ZrP5 & 11.47 & 0.5762 & 17.07 & 16.17 & 14.37 & \\
\hline ZrP25 & 11.58 & 0.3602 & 26.45 & 25.06 & 22.27 & \\
\hline
\end{tabular}

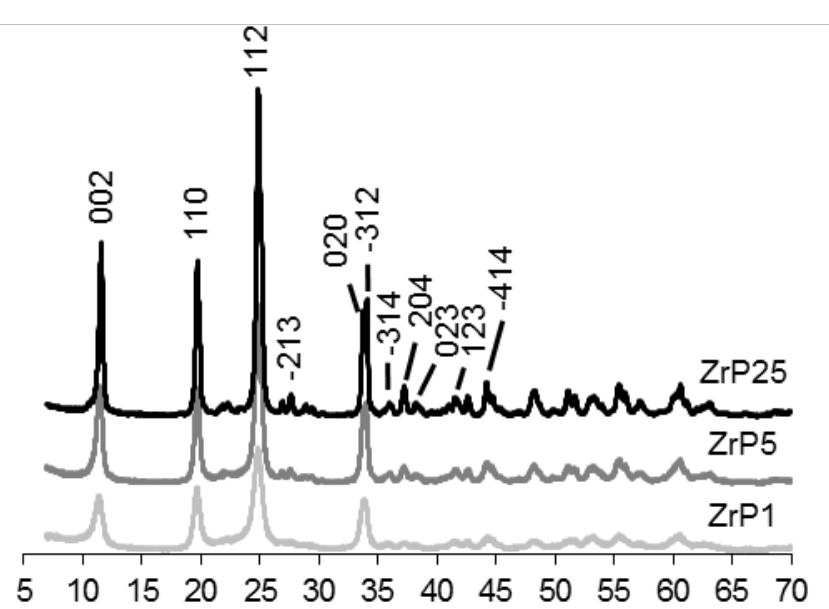

Figure 1. Powder X-ray diffraction patterns with Miller indices for the products ZrP1, ZrP5 and ZrP25, measured in $2 \theta$ range from 7 to $70^{\circ}$ using copper $\mathrm{Ka}$ radiation with scan speed of $0.001^{\circ} \cdot \mathrm{s}^{-1}$.

Recently special attention on layered metal(IV) phosphate research has been given to solid-state ${ }^{31} \mathrm{P}$ MAS NMR techniques to understand and differentiate between various chemically or crystallographically different phosphate groups in these materials, or to study the covalency of binding of intercalated species. ${ }^{[8,13]}$ We use the technique to further debate on the crystallinity of the product - the uniformity of the phosphate groups. Based on literature, ${ }^{[14]}$ in $\alpha$-ZrP, the monohydrogen phosphate groups $\left(\mathrm{HPO}_{4}{ }^{2-}\right)$ bonded to three $\mathrm{Zr}(\mathrm{IV})$ atoms in the $\alpha$-layer show resonances between $-18.7 \mathrm{ppm}$ and $-22.8 \mathrm{ppm}$, while the resonances at -14.8 to $-15.0 \mathrm{ppm}$ and -27.4 to -28.3 ppm belong to the phosphate groups $\mathrm{H}_{2} \mathrm{PO}_{4}^{-}$and $\mathrm{PO}_{4}{ }^{3-}$ bonded to two and four $\mathrm{Zr}(\mathrm{IV})$ atoms, respectively.

The major peak of $\alpha$-ZrP at approx. $-18 \mathrm{ppm}$ is dominating in the case of ZrP25, and as crystallinity decreases, the intensities of the other peaks at -21 ppm and -13 ppm increase (Fig. 2). The major peak widens in the order ZrP25 - ZrP5 - ZrP1, which supports the increase of amorphous character in the products in this order. The amorphous phase NMR is described in our recent publications for both amorphous $\mathrm{ZP}$ and analogous titanium phosphate. ${ }^{[15]}$ The shoulder at -16 ppm was designated to the same $\mathrm{HPO}_{4}{ }^{2-}$ region based on a study on structurally analogous $\alpha$-titanium(IV) phosphate. ${ }^{[16]}$ However, the peak at -13 ppm indicates that there are also dihydrogen phosphate groups present in the case of the most amorphous ZrP1. Similarly only for ZrP1, small peaks at -25 ppm and -27 ppm, designated for $\mathrm{PO}_{4}{ }^{3-}$, were found and taken into account. No peaks for phosphorous more positive than the -13 ppm were detected, indicating the absence of $\mathrm{H}_{3} \mathrm{PO}_{4}$ (peak at $0 \mathrm{ppm}$ ) or the possible alternative crystalline form, $y$-ZrP (major peak at -9 ppm $^{[14 a]}$ ). Peak deconvolution was done with OriginPro 8.6 software (OriginLab), and the relative peak areas for $-13,-16$, $18,-21,-25$ and -27 ppm were determined. The ratios of these peak areas, respectively, were: $4: 3: 53: 37: 1: 2$ for ZrP1, 0:6:65:29:0:0 for ZrP5 and 0:5:76:19:0:0 for ZrP25. As the time for crystallization is increased during the synthesis, more and more perfectly oriented structure is formed, resulting in only one significant peak in ${ }^{31} \mathrm{P}$ M AS NM R at around $-18 \mathrm{ppm}\left(\mathrm{HPO}_{4}{ }^{2-}\right)$. The selected time frame of 25 hours is not enough to form that perfect of a crystal structure - that is at least without added energy from for example a hydrothermal synthesis. All the mentioned chemical shifts are in reference to $85 \% \mathrm{H}_{3} \mathrm{PO}_{4}$. 


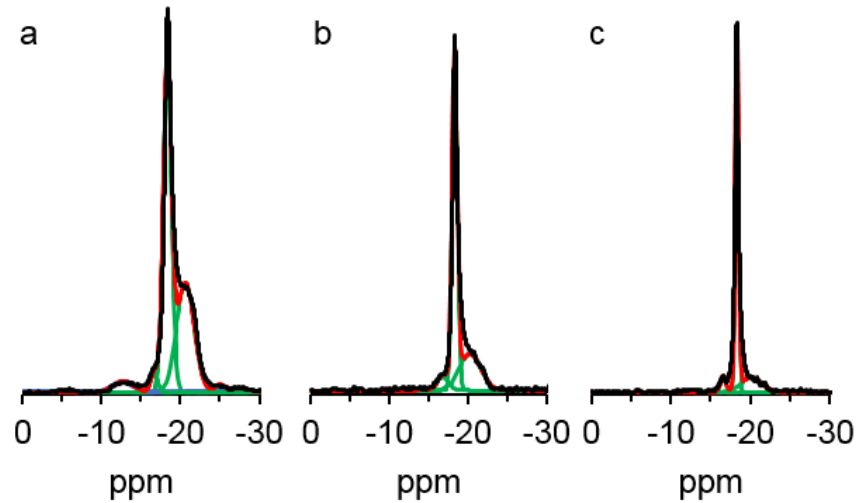

Figure 2. Solid-state ${ }^{31}$ P M AS NM R spectra of the ZrPs in reference to $85 \%$ orthophosphoric acid in ppm: a) ZrP1 b) ZrP5 c) ZrP25. Six significant peaks for were found for $\mathrm{ZrP1}$ and taken into account in calculations: $-13 \mathrm{ppm}\left(\mathrm{H}_{2} \mathrm{PO}_{4}^{-}\right) ;-16,-18$ and $-21 \mathrm{ppm}\left(\mathrm{HPO}_{4}{ }^{2-}\right) ;-25$ and -27 ppm $\left(\mathrm{PO}_{4}{ }^{3-}\right)$, peak designations in parentheses. Three for ZrP5 and ZrP25: -16, -18 and $21 \mathrm{ppm}$.

The products were thermogravimetrically analysed. See Supporting Information for the TGA curves including mass loss and its $1^{\text {st }}$ differential against temperature. A region of more loose water and a region of more bound water was determined. The analysis was continued until temperature of $800{ }^{\circ} \mathrm{C}$, where all the water is removed and only pyrophosphate remains. By combining the results from elemental analysis, TGA and NMR, the chemical compositions were calculated, see Supporting Information for calculations. The compositions were $\mathrm{Zr}\left(\mathrm{H}_{2} \mathrm{PO}_{4}\right)_{0.08}\left(\mathrm{HPO}_{4}\right)_{1.87}\left(\mathrm{PO}_{4}\right)_{0.06} \cdot 0.66 \mathrm{H}_{2} \mathrm{O}, \mathrm{Zr}\left(\mathrm{HPO}_{4}\right)_{2}$. $0.48 \mathrm{H}_{2} \mathrm{O}$ and $\mathrm{Zr}\left(\mathrm{HPO}_{4}\right)_{2} \cdot 0.55 \mathrm{H}_{2} \mathrm{O}$ for $\mathrm{ZrP1}$, ZrP5 and ZrP25 respectively.

Particle morphology was studied with FESEM (Fig. 3). ZrP1 and ZrP5 was noted to form clusters of crystalline regions, clumped together possibly by amorphous phase. This occurrence of amorphous phase is supported by the NM R findings described earlier. As for ZrP25, where the (re)crystallization time was the highest, the large clusters are hardly seen, instead most the particles are separate and in the dimensions of several tens of nanometres, close to the average crystallite size. In Fig. 3, the image series a-c-e and b-d$f$ suggest that as time for crystallization is very limited, only large aggregates of unrefined ZrP are formed. As more time is given, and crystallite size increases, aggregates with more refined details are formed. As crystallite size increases even further, the change in the surface free energy allows crystals to finally grow separate from large aggregates. The particles of ZrP25 look like intermediates between those of ZrP5 and the perfect hexagon shaped platelets of a highly crystalline $\alpha$-ZrP imaged earlier. ${ }^{[17]}$

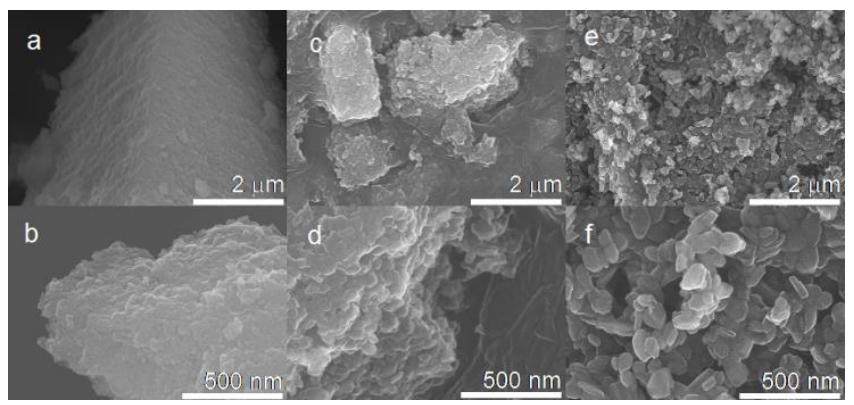

Figure 3. M orphology of the products ZrP1 (a, b), ZrP5 (c, d) and ZrP25 (e, f), imaged with FESEM at 20k (upper row) and 90k (lower row) magnifications.

\section{Ion exchange properties}

First dissociation acid constants $\left(\mathrm{pK}_{\mathrm{a} 1}\right)$, determined with base titration (Fig. 4), were: 6.12 for ZrP1, 6.30 for ZrP5 and 6.88 for ZrP25. The constants were graphically determined from the $\mathrm{pH}$ at the point where degree of dissociation is $50 \%\left(\beta=0.50, \mathrm{pH}=\mathrm{pK}_{\mathrm{a} 1}\right)$. For detailed theory, see Supporting Information, Eqs. 9 to 11. The ion exchange capacity was graphically determined from the final equivalence point of the titration curves: $7 \mathrm{meq} / \mathrm{g}$ for all the three samples. This is slightly more than what is reported for crystalline $\alpha$-ZRP, 6.6 $\mathrm{meq} / \mathrm{g}^{[2 a},{ }^{11 f},{ }^{17]}$ a value that can be rationalized theoretically from the chemical formula. We suggest that this slight increase is due to the partly amorphous nature of the products, which can increase the capacity as discussed in earlier study. ${ }^{[15 b]}$

The logarithms of distribution coefficients for both $\mathrm{Eu}(\mathrm{III})$ and Am(III), studied at trace concentrations, are plotted against equilibrium pH (Fig. 5). Compared to our earlier study done in similar conditions ${ }^{[11 f]}$ the $K_{d}$ values reported here are higher than for two out of the three different $\alpha$-ZrP products discussed in the earlier study, but lower than third - the most amorphous. Compared to the $\mathrm{Kd}$ values reported by M imura and Akiba ${ }^{[10,11 b]}$ for trace level Am and Eu, determined in similar solution conditions, the values reported here for both Am and Eu are a few orders of magnitude higher. This is because of their granulation of the $\alpha$-ZrP with silica, and larger particle size, which both decrease the sorption. 


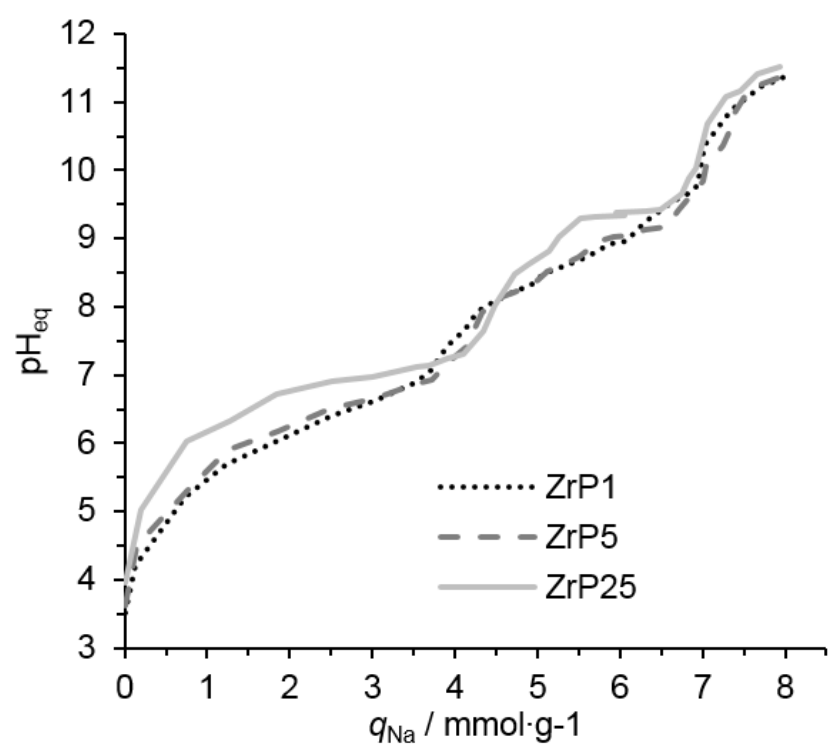

Figure 4. Titration curves for the studied products ZrP1, ZrP5 and ZrP25. The products in pure water were titrated with 1.0 molar $\mathrm{NaOH}$ additions, and equilibrated for 1 day before $\mathrm{pH}$ measurement. $\mathrm{q}_{\mathrm{Na}}$ is the conversion of the $\mathrm{H}$-form product to $\mathrm{Na}$-form, in $\mathrm{mmol} \cdot \mathrm{g}^{-1}$.

The distribution coefficients were found highest in ZrP1 and lowest in $\mathrm{ZrP} 25$ for the whole $\mathrm{pH}$ range for both $\mathrm{Eu}$ and Am. ZrP5 stands between them, albeit very close to $\mathrm{ZrP1}$. These findings are in line with the acidities of the products: $\mathrm{ZrP1}$ is the most acidic and dissociates most readily in low $\mathrm{pH}$, binding more of the metals and giving the largest distribution coefficients, ZrP25 is the least acidic and ZrP5 lies in between. Eu has always the higher distribution coefficient i.e. Eu is more retained in the exchanger. A simple explanation for this would be its smaller effective ionic radius: Eu is able to fit better at the exchange site. The effective ionic radii for $\mathrm{Eu}(\mathrm{III})$ and $\mathrm{Am}$ (III) respectively are: $94.7 \mathrm{pm}$ and 97.5 pm for coordination 6, and $106.6 \mathrm{pm}$ and $109 \mathrm{pm}$ for coordination $8{ }^{[18]}$ As theory states, when exchanging $\mathrm{H}^{+}$for trivalent species, a slope of 3 is expected. Regression parameters for said plots are given in Table 2 , and it is apparent that all the slopes are less than 3. As we have discussed in our earlier study, ${ }^{[11 f]}$ lower than 3 slopes can be explained with the co-exchange of nitrate species with a lower charge, e.g. $\mathrm{Am}\left(\mathrm{NO}_{3}\right)^{2+}$ and $\mathrm{Eu}\left(\mathrm{NO}_{3}\right)^{2+}$. These were determined to exist in large amounts with PHREEQC code simulation in experiment conditions equal to this work. The fact that in the present results Am is further away from the slope of 3 than $\mathrm{Eu}$, is supporting this explanation for the reason that the simulation resulted in higher fraction of divalent Am-nitrate species than corresponding Eunitrates: in $\mathrm{pH} 1$ to $3, \mathrm{Am}\left(\mathrm{NO}_{3}\right)^{2+} 30-40 \mathrm{~mol}-\%$ and $\mathrm{Eu}\left(\mathrm{NO}_{3}\right)^{2+} 10-15 \mathrm{~mol}-\%$. In pH 0 to 1 these percentages are even greater. Separation factors, determined as the ratio of the always larger $K_{d}(E u)$ to the smaller $K_{d}(A m)$, were calculated (Table 2). For such similar analytes like Eu and Am, we find the determined separation factors from 10 to 100 promising for column use.

Table 2. Linear regression parameters for distribution coefficients as a function of equilibrium $\mathrm{pH}$. Separation factors (Kd Eu : Kd Am) for the three ZrPs in selected $\mathrm{pH}$.

\begin{tabular}{lllll}
\hline & & ZrP1 & ZrP5 & ZrP25 \\
\hline Slope & Eu & 2.804 & 2.858 & 2.959 \\
\hline & $\mathrm{Am}$ & 2.595 & 2.885 & 2.790 \\
\hline Intercept & $\mathrm{Eu}$ & 1.230 & 1.158 & 0.339 \\
\hline & $\mathrm{Am}$ & 0.215 & -0.568 & -1.023 \\
\hline $\mathrm{R}^{2}$ & $\mathrm{Eu}$ & 0.997 & 0.984 & 0.995 \\
\hline & $\mathrm{Am}$ & 0.997 & 0.963 & 0.976 \\
\hline $\begin{array}{l}\text { Separation } \\
\text { factors }\end{array}$ & $\mathrm{pH}$ & $\mathrm{ZrP1}$ & $\mathrm{ZrP5}$ & $\mathrm{ZrP25}$ \\
\hline & & & & \\
\hline & 0.5 & 26 & 93 & 6 \\
\hline & 1.0 & 32 & 63 & 54 \\
\hline & 1.5 & 20 & 19 & 28 \\
\hline & 2.0 & 4 & 6 & 9 \\
\hline
\end{tabular}

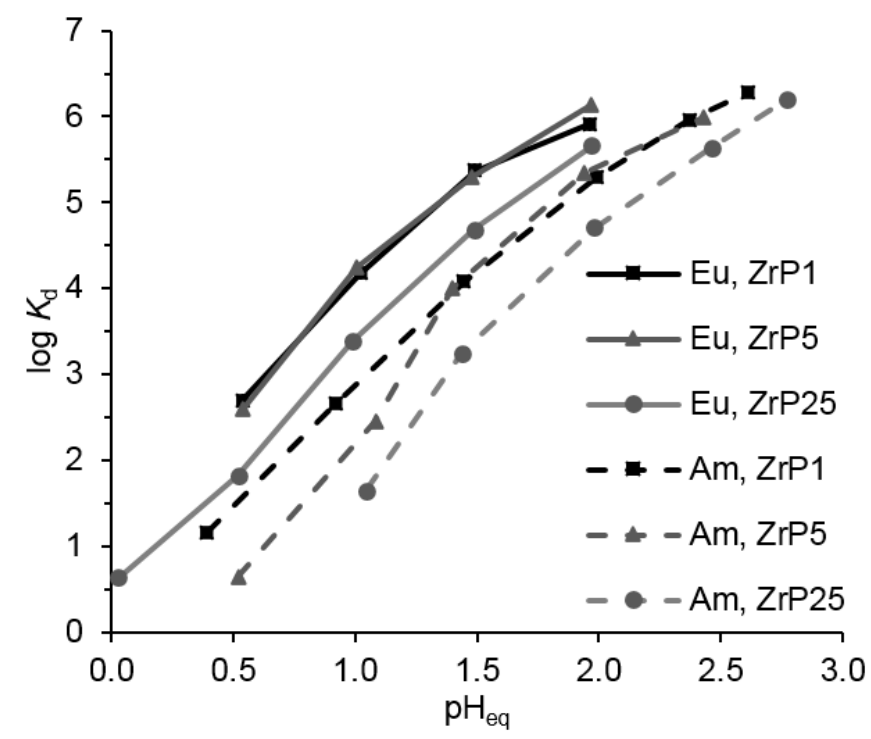

Figure 5. Distribution coefficients $\left(K_{d}\right)$ for ZrP1, ZrP5 and ZrP25 in $0.001 \mathrm{~mol} \cdot \mathrm{L}^{-1}$ to $1 \mathrm{~mol} \cdot \mathrm{L}^{-1} \mathrm{HNO}_{3}$ with $\mathrm{NaNO}_{3}$ background.

Selectivity coefficients (log $\left.\mathrm{K}_{M / H}\right)$ were determined for $\mathrm{Eu} / \mathrm{H}$ and $\mathrm{Am} / \mathrm{H}$ (Table 3 ) with the use of the $K_{d}$ linear regression parameters and the total ion exchange capacity $(7 \mathrm{meq} / \mathrm{g})$. This parameter gives the affinity of $\mathrm{Eu}$ or Am over $\mathrm{H}$ in the exchanger. Metal binding coefficients were determined using selectivity coefficients and first acid dissociation constants (Table 3). This describes the raw affinity of the exchanger for an ion. See Supporting Information for the theory and calculations behind distribution-, selectivity- and metal 
binding coefficients; all theory and calculations are based on the works of Harjula ${ }^{[19]}$ and Helfferich. ${ }^{[20]}$ While the metal binding is strongest in ZrP25 for both $\mathrm{Eu}$ and $\mathrm{Am}$ and weakest in $\mathrm{ZrP1}$, the selectivity coefficients show a reverse order (Fig. 6). This is because the materials are so weakly acidic, i.e. have large $\mathrm{pK}_{\mathrm{a} 1}$ values, which results in $\mathrm{pK}_{\mathrm{a} 1}$ being prominent in the calculation $\left(\log \mathrm{k}_{\mathrm{M} / \mathrm{H}}=\log \mathrm{k}_{\mathrm{M}}-3 \cdot \mathrm{pK}_{\mathrm{a}}\right)$. To put it in other words: For both Eu and Am, ZrP25 has the smallest selectivity coefficients even though it has the strongest metal binding, because of its lesser acidity compared to ZrP1 and ZrP5.

Table 3. Selectivity coefficients and metal binding coefficients for Eu(III) and Am(III) for the three ZrP products.

\begin{tabular}{lllll}
\hline & & ZrP1 & ZrP5 & ZrP25 \\
\hline $\log _{\mathrm{K}_{M} / \mathrm{H}^{[a]}}$ & Eu & -1.305 & -1.377 & -2.195 \\
\hline & $\mathrm{Am}$ & -2.320 & -3.103 & -3.559 \\
\hline $\log _{\mathrm{K}_{M}}{ }^{[\mathrm{b}]}$ & $\mathrm{Eu}$ & 17.055 & 17.523 & 18.445 \\
\hline & $\mathrm{Am}$ & 16.040 & 15.797 & 17.081 \\
\hline
\end{tabular}

[a] $\log k_{M / H}=I C-Z_{M} \cdot \log Q$. [b] $\log k_{M}=\log k_{M / H}+3$. $\mathrm{pK}_{\mathrm{a} 1} \cdot \mathrm{M}=\mathrm{Am}(\mathrm{III}), \mathrm{Eu}(\mathrm{III}) \cdot \mathrm{Z}_{\mathrm{M}}=3 . \mathrm{IC}=$ intercept in regression of $\log \mathrm{K}_{d} \mathrm{Vs}$. $\mathrm{pH}$ eq. $\mathrm{Q}=7.0 \mathrm{meq} / \mathrm{g}$.

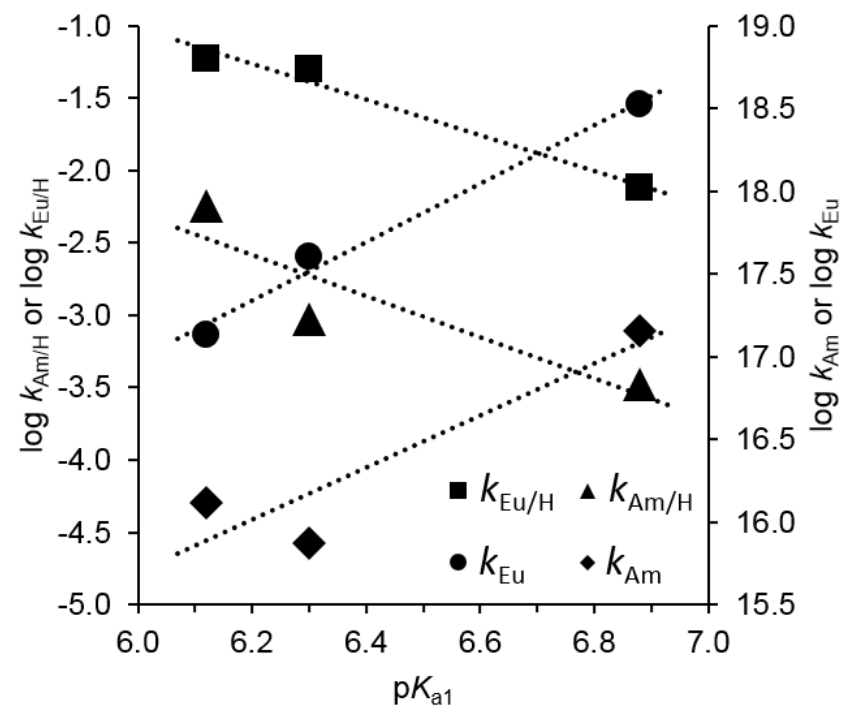

Figure 6 . The selectivity coefficients $\mathrm{k}_{M / H}$ and metal binding coefficients $\mathrm{k}_{\mathrm{M}}$ plotted as a function of $\mathrm{pK}_{\mathrm{a} 1}$ values for the exchangers ZrP1, ZrP5 and ZrP25 ( $M=E u$, Am).

\section{Conclusions}

In this paper we have reported of a study done on a modification on $\alpha$-zirconium phosphate: the time for (re)crystallization during the synthesis. Three aliquots from the same synthesis vessel were evacuated after crystallization time of 1,5 and 25 hours. The rest of the syntheses were done separately but in strictly equal manner, to result in the three products $\mathrm{ZrP1}, \mathrm{ZrP5}$ and ZrP25. For these products, several parameters and their trends - shown here in increasing order in parentheses - were determined: first acid dissociation constants (ZrP1 < ZrP5 < ZrP25), distribution coefficients in nitric acid for Eu(III) and Am(III) (ZrP25 < ZrP5 $<$ ZrP1), separation factors, selectivity coefficients for Eu/H and Am/H (ZrP25 < ZrP5 <ZrP1) and metal binding coefficients (ZrP1 <ZrP5 <ZrP25).

From the results it was apparent that longer crystallization time resulted in less acidic product. The most crystalline and the least acidic product ZrP25 had the strongest metal binding, but because of its larger acid constant, it had the lowest selectivity coefficients for both $\mathrm{Eu}(\mathrm{III})$ and $\mathrm{Am}(\mathrm{III})$ at the studied $\mathrm{pH}$ range of 0 to 3. NM R study suggests that the products of lesser crystallinity ZrP1 and ZrP5 had multiple significant phosphorous sites with different chemical surroundings, while the most crystalline ZrP25 had one major type of phosphorous. It is important to note that for trace exchange however, the minor phosphate groups could as well be of importance. To summarize, increasing time for crystallization increased crystallinity - and crystallite size, which in turn lowered the acidity of the material. Crystalline and acid character of a product then dictates its ion exchange properties and applicability for separation use. While the time can be increased further or other methods can be used to get more crystalline product, our findings here support our previous studies ${ }^{[11 f, 15 b, 17]}$ in that a too highly crystalline product will have less favourable ion exchange properties in low $\mathrm{pH}$. This highlights that the most readily available ion exchange sites exist on surfaces, edges and in crystal defect sites. As a future prospect, this could be further investigated even in more crystalline materials by the means of doping the material with a metal that is not analogous to $\mathrm{Z}$ (IV) to introduce more defects.

This study paves way for development of trivalent actinide-lanthanide column separation methods based inorganic ion exchange and simple mineral acid solutions. For future binary separation studies in columns, we consider a good candidate to have low $\mathrm{K}_{d}$ for one analyte, e.g. less than 100 , while as high as possible for the other. In most of the studied $\mathrm{pH}$ range, ZrP1 has too high of an uptake for both Eu and Am. For $\mathrm{pH}$ range from 0.5 to $1.0, \mathrm{ZrP} 5$ is deemed most suitable with a separation factor from 60 to 90 , and for $\mathrm{pH}$ range from 1.0 to $1.5, \mathrm{ZrP25}$ with a separation factor from 30 to 50 . Column studies are being conducted and will be reported later. 


\section{Supporting Information Summary}

Experimental details, theory and calculus on the various coefficients mentioned in the main text, and details on the chemical composition determination are all available in Supporting Information, along with the figures for infrared spectroscopy and thermogravimetric analysis.

\section{Acknowledgements}

In memoriam honorary professor Risto 0 . Harjula, a great mind in the field of inorganic ion exchangers and radionuclide removal.

The authors would like to thank Dženita Avdibegović from KU Leuven for ICP-OES measurements. The research is funded by State Nuclear Waste Management Fund, on the basis of proposals by the M inistry of Employment and Education of Finland. It is part of Finnish Research Programme on Nuclear Waste Management which is based on the Nuclear Energy Act (990/ 1987).

\section{Keywords}

Actinides; Inorganic synthesis; Ion exchange;

Lanthanides; Zrconium phosphate

\section{References}

[1] A. Clearfield, J. A. Stynes, J. Inorg. Nucl. Chem. 1964, 26, 117-129.

[2] a) A. Clearfield, Ann. Rev. Mater. Sci. 1984, 14, 205-229; b) A. Clearfield, G. D. Smith, Inorg. Chem. 1969, 8, 431.

[3] G. Alberti, E. Torracca, A. Conte, J. Inorg. Nucl. Chem. 1966, 28, 607-613.

[4] G. Alberti, U. Costantino, J. Chromatogr. 1974, 102, 5-29.

[5] a) A. Clearfield, D. S. Thakur, Appl. Catal. 1986, 26, 1-26; b) M. Pica, Catalysts 2017, 7.

[6] a) G. Alberti, U. Costantino, S. Allulli, N. Tomassini, J. Inorg. Nucl. Chem. 1978, 40, 1113-1117; b) A. Clearfield, Curr. Opin. Solid State M ater. Sci. 1996, 1, 268-278; c) Y.-P. Zhu, T.-Y. Ma, Y.-L. Liu, T.-Z. Ren, Z.-Y. Yuan, Inorg. Chem. Front. 2014, 1, 360-383.

[7] a) J. L. Colón, B. Casañas, in Tailored OrganicInorganic Materials (Eds.: E. Brunet, J. L. Colón, A. Clearfield), John Wiley $\&$ Sons, Inc, Hoboken, NJ, 2015; b) A. Díaz, A. David, R. Pérez, M. L. González, A. Báez, S. E. Wark, P. Zhang, A. Clearfield, J. L. Colón, Biomacromolecules 2010, 11, 2465-2470.

[8] B. M. Mosby, A. Diaz, A. Clearfield, Dalton Trans. 2014, 43, 10328-10339.
[9] L. Szirtes, K. Lázár, E. Kuzmann, Radiat. Phys. Chem. 1999, 55, 583-587.

[10] H. Mimura, K. Akiba, J. Nucl. Sci. Technol. 1995, 32, 819.

[11] a) F. L. M oore, Anal. Chem. 1971, 43, 487-489;

b) H. Mimura, K. Akiba, J. Nucl. Sci. Technol. 1996, 33, 592-596; c) J. D. Burns, A. Clearfield, M. Borkowski, D.T. Reed, Radiochim. Acta 2012, 100, 381; d) R. Silbernagel, T. C. Shehee, C. H. Martin, D. T. Hobbs, A. Clearfield, Chem. M ater. 2016, 28, 2254-2259; e) B. R. Selvan, K. Dasthaiah, A. S. Suneesh, K. A. Venkatesan, M. P. Antony, R. L. Gardas, Radiochim. Acta 2017, 105, 275; f) E. W. Wiikinkoski, R. O. Harjula, J. K. Lehto, M. L. Kemell, R. T. Koivula, Radiochim. Acta 2017, 100, 1033; g) J. Xu, S. Virolainen, W. Zhang, J. Kuva, T. Sainio, R. Koivula, Chem. Eng. J. 2018, 351, 832-840.

[12] T. J. B. Holland, S. A. T. Redfern, Mineral. Mag. 1997, 61,65 .

[13] a) H. Nakayama, T. Eguchi, N. Nakamura, S. Yamaguchi, M. Danjyo, M. Tsuhako, J. Mater. Chem. 1997, 7, 1063-1066; b) V. I. Bakhmutov, A. Clearfield, J. Phys. Chem. 2016, 120, 19225-19233; c) W. Zhang, D. Avdibegovic, R. Koivula, T. Hatanpaa, S. Hietala, M. Regadio, K. Binnemans, R. Harjula, J. M ater. Chem. A 2017, 5, 23805-23814; d) V. I. Bakhmutov, Y. Kan, J. A. Sheikh, J. GonzálezVillegas, J. L. Colón, A. Clearfield, M agn. Reson. Chem. 2017, 55, 648-654.

[14] a) N. J. Clayden, Dalton Trans. 1987, 18771881; b) D. J. M acLachlan, K. R. M organ, J. Phys. Chem. 1990, 94, 7656-7661; c) M. Casciola, D. Capitani, A. Comite, A. Donnadio, V. Frittella, M. Pica, M. Sganappa, A. Varzi, Fuel Cells 2008, 8, 217-224; d) M. Casciola, D. Capitani, A. Donnadio, V. Frittella, M. Pica, M. Sganappa, Fuel Cells 2009, 9, 381-386; e) M. Pica, A. Donnadio, D. Capitani, R. Vivani, E. Troni, M. Casciola, Inorg. Chem. 2011, 50, 11623-11630.

[15] a) W. Zhang, R. T. Koivula, E. Wiikinkoski, J. Xu, S. Hietala, J. Lehto, R. Harjula, ACS Sustainable Chem. Eng. 2017, 5, 3103-3114; b) J. Xu, R. Koivula, W. Zhang, E. Wiikinkoski, S. Hietala, R. Harjula, Hydrometallurgy 2018, 175, 170-178.

[16] M. Trublet, M. V. Maslova, D. Rusanova, O. N. Antzutkin, M ater. Chem. Phys. 2016, 183, 467475.

[17] J. Xu, E. Wiikinkoski, R. T. Koivula, W. Zhang, B. Ebin, R. Harjula, J. Sustain. M etall. 2017, 3, 646658.

[18] R. Shannon, Acta Crystallogr., Sect. A 1976, 32, 751-767.

[19] R. Harjula, in Encyclopedia of Separation Science, Vol. 2 (Eds.: I. D. Wilson, C. F. Poole, T. 
R. Adlard, M. Cooke), Academic Press, London,

2000, pp. 1651-1661.

[20] F. Helfferich, Ion Exchange, Dover, New York, 1995.

Suggestion for Table of Contents figure and 80-word text (opt for $5.5 \mathrm{~cm} \times 5 \mathrm{~cm}$ ratio).

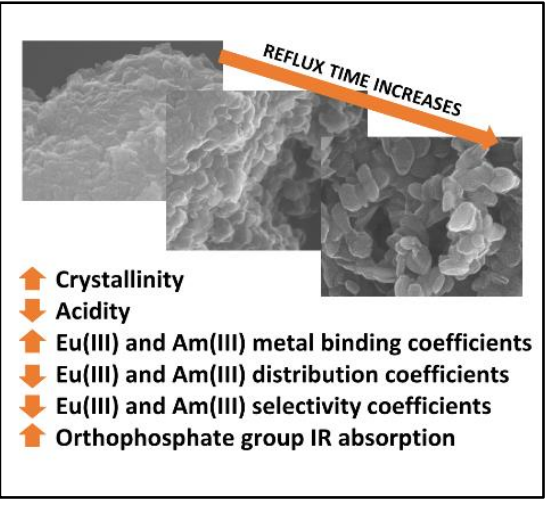

Simultaneous one-pot synthesis resulted in three $\alpha$-zirconium phosphate products of varying crystallinity and acidity. The effect of these properties on other material properties as well as Eu(III) and Am(III) ion exchange properties were investigated with separation of these similar elements in mind. Separation factors of up to 90 (Eu:Am) were achieved in $\mathrm{pH}$ less than 1. It was found that with simple modification of the synthesis, one can obtain a product suitable for uptake or separation varying different $\mathrm{pH}$ range. 